\title{
Allred Total Score
}

National Cancer Institute

\section{Source}

National Cancer Institute. Allred Total Score. NCI Thesaurus. Code C125987.

The histopathological evaluation of staining in tissue based on the Allred scoring system (Allred DC, Harvey JM, Berardo M, Clark GM. Prognostic and predictive factors in breast cancer by immunohistochemical analysis. Mod Pathol. 1998 Feb;11(2):155-68). 